\title{
Pencegahan Tindak Pidana Pedofilia Sebagai Upaya Perlindungan Kesehatan Anak di Indonesia
}

\author{
Prameswara Winriadirahman \\ Magister Hukum Fakultas Hukum Universitas Islam Indonesia Yogyakarta Indonesia \\ Jln. Cik Di Tiro No. 1 Yogyakarta Indonesia \\ prameswarawr@gmail.com
}

\begin{abstract}
The crime of pedophilia is a complex legal problem because there are many obstacles that occur in its implementation. Departing from this, this study aims to analyze how prevention and protection efforts by the government are in dealing with pedophilia crimes and how to protect and prevent children from pedophilia crimes. The method used in this research is a descriptive non-doctrinal legal research with a juridical-sociological approach, where the information obtained comes from interviews, while the data comes from a literature study. The results conclude that the government has implemented various efforts to protect and prevent pedophile crimes against children by making various work programs that are supported by the community and community organizations. However, due to the complexity of the problem of criminal acts of pedophilia, there are still many obstacles experienced to overcome these problems.
\end{abstract}

Key Words: Children's health; legal protection; pedophilia

\begin{abstract}
Abstrak
Tindak pidana pedofilia adalah permasalahan hukum yang kompleks karena ada banyak hambatan yang teriadi dalam pelaksanaannya. Berangkat dari hal tersebut, penelitian ini bertujuan untuk menganalisis bagaimana upaya pencegahan dan perlindungan oleh pemerintah dalam menangani tindak pidana pedofilia dan cara melindungi serta mencegah anak dari tindak pidana pedofilia. Metode yang digunakan dalam penelitian ini adalah penelitian hukum non-doktrinal yang bersifat deskriptif dengan pendekatan yuridis-sosiologis, dimana informasi yang didapatkan berasal dari wawancara, sedangkan data dari studi kepustakaan. Hasilnya menyimpulkan bahwa pemerintah telah melaksanakan berbagai upaya perlindungan dan pencegahan tindak pidana pedofil pada anak-anak dengan membuat berbagai program kerja yang didukung oleh masyarakat dan organisasi masyarakat. Namun, karena rumitnya permasalahan tindak pidana pedofilia masih banyak kendala yang dialami untuk menanggulangi permasalahan tersebut.
\end{abstract}

Kata-kata Kunci: Perlindungan hukum; pedofilia; kesehatan anak 


\section{Pendahuluan}

Hakikatnya manusia merupakan makhluk yang bersifat mono-prulalis, yaitu makhluk yang memiliki sifat ketidakberdayaan dan ketidakmampuan. Anak sejak dilahirkan mempunyai sifat-sifat tertentu untuk menyesuaikan diri dengan lingkungannya. Seperti diketahui bahwa anak merupakan potensi dan penerus cita-cita bangsa, yang dasarnya telah diletakkan oleh generasi sebelumnya. Jika generasi baru ini dijaga dan dipelihara dengan baik, maka anak akan tumbuh dan berkembang dengan baik pula sesuai dengan keinginan dan harapan. ${ }^{1}$

Anak sesungguhnya merupakan investasi dan harapan masa depan bangsa serta sebagai penerus generasi di masa mendatang. Pada siklus kehidupan, fase anak-anak merupakan suatu tahapan dimana anak-anak mengalami tumbuh kembang yang dapat menentukan masa depannya. Tumbuh kembang anak menjadi sangat penting karena selain krusial, perhatian dan kasih sayang dari keluarga terutama dari orang tua juga sangat dibutuhkan bagi anak, sehingga pada dasarnya hak dan kebutuhan anak dapat dipenuhi secara baik. ${ }^{2}$

Cita ideal masyarakat secara umum menginginkan anak-anaknya tumbuh dengan sehat, ceria, cerdas, serta terjamin kelangsungan hidupnya agar terjamin tumbuh kembang mereka. Namun realitas sosial yang terjadi memperlihatkan adanya perbedaaan, bahkan kadang-kadang menyimpang dengan apa yang kita harapkan. ${ }^{3}$ Melindungi anak menjadi suatu kewajiban agar mereka tidak menjadi korban tindakan berbagai pihak baik secara langsung maupun tidak langsung. Pada hakikatnya anak tidak dapat melindungi diri sendiri dari berbagai macam tindakan yang menimbulkan kerugian baik mental, fisik, maupun sosial dalam berbagai bidang kehidupan dan penghidupan. Anak membutuhkan bantuan oleh orang lain dalam melindungi dirinya, karena situasi dan kondisinya. Anak sangat memerlukan berbagai macam perlindungan agar tidak mengalami kerugian, baik mental, fisik maupun sosial. ${ }^{4}$

Dewasa ini semakin sering kita mendengar tentang kekerasan seksual yang dilakukan terhadap anak. Anak dianggap rentan mendapatkan perlakuan kekerasan seksual karena masih banyak yang belum mengerti tentang pelajaran seksual dan fisik mereka yang cenderung lemah dibandingkan orang dewasa. Perlakuan kekerasan seksual tidak hanya dialami oleh anak perempuan, namun anak laki-laki. Dari data yang diperoleh dari website Komisi Perlindungan Anak

\footnotetext{
${ }^{1}$ Abu Huraerah, Kekerasan Terhadap Anak, Nusantara, Bandung, 2006, hlm. 18.

2 Ratna Sari et.al., "Pelecehan Seksual Terhadap Anak", Riset \& PKM, edisi No. 1 Vol. 2, 2015, hlm. 14.

${ }^{3}$ Hadi Supeno, Kriminalisasi Anak, Gramedia Pustaka Utama, Jakarta, 2010, hlm. 69.

${ }^{4}$ Maidin Gultom, Perlindungan Hukum Terbadap Anak dan Perempuan, Refika Aditama, Bandung, 2018, hlm.
} 69. 
Indonesia, menurut Susanto data sementara pada 2018 ada 223 anak laki-laki yang menjadi korban dengan berbagai modus. ${ }^{5}$ Data ini dapat bertambah karena dimungkinkan masih banyak kasus yang tidak dilaporkan, diterima, atau diperbaharui oleh KPAI.

Ditambah lagi adanya suatu kasus mengenai pencabulan yang dilakukan oleh pelaku pedofil berinisial FCR di Sukabumi yang diduga telah menyodomi 30 anak laki-laki. Adanya sebuah temuan baru yang dilakukan oleh Polres Sukabumi ini menunjukkan bahwa perbuatan kekerasan seksual terhadap anak atau pedofilia masih terjadi hingga sekarang. ${ }^{6}$ Kasus yang lebih besar terulang, yaitu adanya tindakan pedofilia yang dilakukan oleh warga negara asing berkewarganegaraan Perancis, Fracois Abello Camille atau Frans yang berusia 65 tahun. Ia ditangkap di salah satu hotel di Jakarta Barat. Frans diduga telah melakukan eksploitasi anak dan kekerasan seksual terhadap 305 anak sejak 2015 hingga 2020.7 Tidak hanya itu, dalam melaksanakan perlindungan hukum, para korban masih dibayangi rasa tidak aman. Seperti yang terjadi di Lampung Timur. Seorang anak perempuan yang sedang dititipkan di rumah aman milik lembaga pemerintah Pusat Pelayanan Terpadu Pemberdayaan Perempuan dan Anak P2TP2A Lampung Timur justru mengalami tindakan kekerasan seksual oleh kepala UPT P2TP2A itu sendiri. ${ }^{8}$

Banyaknya kasus kekerasan seksual terhadap anak menjadi suatu perhatian khusus yang harus segera diselesaikan. Perlindungan hukum bagi anak-anak agar tumbuh kembangnya menjadi maksimal menjadi suatu hal yang penting. Namun, dalam pelaksanaannya ada pelanggaran yang dilakukan oleh oknum yang tidak bertanggung jawab, bahkan saat berada di sebuah lembaga perlindungan oleh pemerintah anak masih saja bisa merasakan rasa tidak aman seperti dalam kasus di atas.

Kekerasan seksual yang dilakukan terhadap anak tidak hanya akan merusak fisik para korban saja. Lebih dari itu, akan ada efek negatif yang dihadapi oleh para korban baik dalam jangka pendek maupun jangka panjang terhadap

5 Davit Setyawan, (20 Maret 2018), KPAI: Kekerasan Anak Laki-Laki Meningkat, https://www.kpai.go.id/berita/kpai-kekerasan-seksual-anak-laki-laki-meningkat, diakses pada tanggal 6 April 2020, pukul 14.50 WIB.

${ }^{6}$ M Rizal Jalaludin, Pelaku Pedofil di Sukabumi Cabuli 30 Anak Laki-laki, Tulis Nama Korban di Tembok. Kamar, https://www.tribunnews.com/regional/2020/07/06/pelaku-pedofil-di-sukabumi-cabuli-30-anak-lakilaki-tulis-nama-korban-di-tembok-kamar?page=all diakses pada tanggal 7 Juli 2020, pukul 19.23 WIB.

${ }^{7}$ Bilal Ramadhan, WNA Pedofil Kerap Pukuli Korbannya, https://republika.co.id/berita/qd8j0u330/wnapedofil-kerap-pukuli-korbannya diakses pada tanggal 22 Juli 2020, pukul 18.35 WIB.

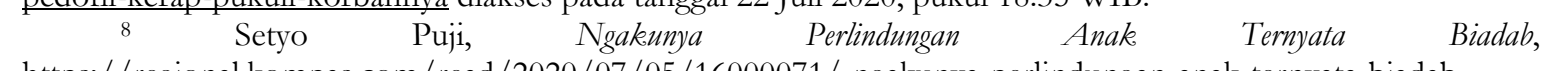
https://regional.kompas.com/read/2020/07/05/16000071/-ngakunya-perlindungan-anak-ternyata-biadab?page $=$ all\#page2 diakses pada tanggal 22 Juli 2020, pukul 18.00 WIB. 
perkembangan emosional, psikologi dan sosial korban kekerasan seksual. ${ }^{9}$ Pelaku kekerasan seksual pada anak biasanya adalah orang dewasa yang lingkupnya berdekatan dengan korban baik itu lingkungan yang berasal dari keluarga maupun orang-orang di lingkungan tempat tinggal atau aktivitas anak itu berada. Pelaku dalam kasus ini sendiri sering disebut sebagai seorang pedofilia. Arti kata pedofilia sebenarnya adalah cinta kepada anak-anak, namun terjadi perkembangan pemaknaan seiring berjalannya waktu, sehingga secara umum digunakan sebagai istilah untuk menjelaskan salah satu kelainan psikoseksual dimana individu memiliki hasrat erotis yang tidak normal terhadap anak-anak. ${ }^{10}$

Korban pedofilia sangat membutuhkan pertolongan dalam menyembuhkan luka fisik maupun psikis mereka. Korban pedofilia masih harus melanjutkan kehidupannya yang seharusnya tidak dibayangi bayangan ketakutan akan adanya tindakan kekerasan seksual yang terjadi pada masa lalu. Tumbuh kembang para anak-anak korban pedofilia dapat terganggu, lebih dari itu para korban berkemungkinan mendapatkan trauma yang menjadikan dirinya sebagai pelaku pedofilia di usia dewasa. Hal ini sangatlah menjadi perhatian penting bagi para pihak khususnya pemerintah untuk melakukan perlindungan, terlebih lagi pencegahan agar tidak terjadi tindakan berulang. Kesehatan anak-anak korban pedofilia sangatlah penting untuk segera disembuhkan. Namun sebuah pencegahan juga sama pentingnya agar tidak menimbulkan korban selanjutnya dan memutus mata rantai pedofilia.

Dalam rangka pelaksanaan perlindungan anak efektif, rasional positif, bertanggung jawab dan bermanfaat, maka ada beberapa syarat yang harus dipenuhi salah satunya adalah tidak menimbulkan rasa tidak dilindungi. Maksudnya adalah pelaksanaan perlindungan anak tidak boleh menimbulkan rasa tidak dilindungi pada yang bersangkutan karena adanya penimbulan penderitaan, kerugian oleh partisipan tertentu. Perlindungan anak harus bersifat pencegahan atau preventif. ${ }^{11}$

Upaya pencegahan atau preventif dirasa sangat penting sama dengan penjatuhan hukuman yang berat bagi para pelaku kekerasan seksual terhadap anak. Selain itu, perlindungan hukum sangatlah dibutuhkan bagi para korban pedofilia agar dapat menyembuhkan luka lahir maupun batin yang mereka terima. Tidak mudah bagi para korban untuk bisa sembuh total maka dari itu pemerintah harus memberikan perhatian khusus dan serius bagi mereka.

\footnotetext{
${ }^{9}$ Muhammad Zubedy Koteng, Upaya Pencegahan Dan Penangnan Kejahatan Seksual Terahadap Anak, Warta Hukum dan HAM, Humanis Volume 1 XII Juli 2016, hlm. 9.

10 Sawitri Suparti Sadarjoen, Bunga Rampai Kasus Gangguan Psikoseksual, Bandung, Refika Aditama, 2005, hlm. 71.

${ }^{11}$ Shanty Dellyana, Wanita dan Anake di Mata Hukum, Liberty, Yogyakarta, 2004, hlm. 19-22.
} 


\section{Rumusan Masalah}

Berdasarkan latar belakang masalah di atas, maka rumusan masalah yang diteliti dalam tulisan ini adalah: pertama, bagaimana upaya pencegahan dan perlindungan oleh pemerintah dalam menangani tindak pidana pedofilia; Kedua, bagaimana cara melindungi serta mencegah anak dari tindak pidana pedofilia.

\section{Tujuan Penelitian}

Sesuai dengan rumusan masalah maka tujuan dari penelitian ini adalah pertama, untuk mengetahui bagaimana upaya pencegahan dan perlindungan oleh pemerintah dalam menangani tindak pidana pedofilia. Kedua, serta untuk mengetahui cara melindungi dan mencegah anak dari tindak pidana pedofilia.

\section{Metode Penelitian}

Penelitian ini merupakan penelitian hukum non-doktrinal yang bersifat deskriptif dengan pendekatan yuridis-sosiologis (sosio-legal research). Maksud dari penelitian ini adalah memadukan bahan-bahan hukum primer dan sekunder dengan permasalahan mengenai pelaksanaan pencegahan yang dilakukan oleh pemerintah tentang tindak pidana kekerasan seksual terhadap anak serta pelaksanaan perlindungan hukum dan rehabilitasi bagi para korban tindak pidana kekerasan seksual terhadap anak. Sumber data primer dan sekunder ini diperoleh dari informan atau narasumber di Komisi Perlindungan Anak Indonesia Daerah Kota Yogyakarta serta bahan-bahan hukum seperti undangundang dan peraturan terkait pencegahan perlindungan anak. Bahan-bahan hukum dan bahan non hukum yang diperoleh dalam penelitian ini akan dianalisis secara prespkriptif dengan metode deduktif.

\section{Hasil Penelitian dan Pembahasan}

\section{Upaya Pencegahan dan Perlindungan oleh Pemerintah dalam Menangani Tindak Pidana Pedofilia}

Hukum memiliki fungsi sebagai pelindung kepentingan manusia. Selain itu, hukum mempunyai sebuah tujuan yang hendak dicapai. Tujuan pokok hukum yaitu menciptakan tatanan masyarakat yang tertib, menciptakan ketertiban dan keseimbangan. Dengan tercapainya ketertiban di dalam masyarakat, diharapkan kepentingan setiap individu manusia akan terlindungi. Untuk mencapai tujuan tersebut maka hukum bertugas membagi antara hak dan kewajiban antar individu/kelompok di dalam masyarakat, membagi wewenang dan mengatur 
bagaimana memecahkan suatu permasalah hukum serta memelihara kepastian hukum. ${ }^{12}$

Menurut Hadjon, perlindungan hukum bagi rakyat meliputi dua hal, yakni:

a) Perlindungan hukum bersifat preventif atau pencegahan, yaitu bentuk perlindungan hukum dimana rakyat diberikan kesempatan untuk mengajukan keberatan atau pendapatnya sebelum adanya aturan hukum atau keputusan pemerintah mendapat bentuk yang tetap atau sah. Tujuannya adalah mencegah terjadinya perselisihan. Perlindungan hukum preventif sangat besar artinya bagi langkah pemerintahan yang didasarkan pada kebebasan bertindak, karena dengan adanya perlindungan hukum yang preventif pemerintah akan terdorong untuk lebih berhati-hati dalam mengambil ketentuan yang didasarkan pada diskresi. Di Indonesia belum ada pengaturan khusus mengenai perlindungan hukum preventif;

b) Perlindungan hukum represif atau pemaksaan, yaitu bentuk perlindungan hukum yang bertujuan untuk menyelesaikan suatu permasalahan. Penanganan perlindungan hukum represif contohnya adalah penanganan sengketa oleh Pengadilan Umum dan Pengadilan Administrasi. Prinsip perlindungan hukum terhadap tindakan pemerintah berpijak dan bersumber dari konsep tentang pengakuan dan perlindungan terhadap hak-hak asasi manusia karena menurut sejarah dari barat, munculnya berbagai konsep tentang pengakuan dan perlindungan terhadap hak-hak asasi manusia ditujukan kepada pembatasan-pembatasan dan penempatan kewajiban masyarakat dan pemerintah. Prinsip kedua yang menjadi dasar perlindungan hukum terhadap tindak pemerintahan adalah prinsip negara hukum. Perlindungan dan pengakuan terhadap hak asasi manusia menajadi tujuan utama dan berkaitan juga dengan tujuan dari negara hukum. ${ }^{13}$

Perlindungan anak suatu masyarakat, bangsa, merupakan tolok ukur peradaban masyarakat, bangsa tertentu. Maka demi pertumbuhan manusia seutuhnya dan beradaban, maka kita wajib memaksimalkan upaya perlindungan anak sesuai dengan kemampuan, demi kepentingan nusa dan bangsa. Kegiatan perlindungan anak merupakan sebuah tindakan hukum yang mempunyai akibat hukum. Maka dari itu perlu adanya jaminan hukum pada setiap kegiatan perlindungan anak tersebut. Kepastian hukum kegiatan perlindungan hukum perlu diupayakan demi kelangsungan kegiatan perlindungan anak dan mencegah penyelewengan yang mengakibatkan dampak negatif yang tidak diinginkan dalam pelaksanaan kegiatan perlindungan anak. ${ }^{14}$

Permasalahan pedofilia sudah menjadi suatu permasalahan yang nyata. Perilaku pedofilia sebagai bentuk patologi sosial yang diderita oleh seseorang

12 Sudikno Mertokusumo, Mengenal Hukum (Suatu Pengantar), Liberty, Yogyakarta, 1999, hlm. 71.

13 Ibid., hlm. 40.

${ }^{14}$ Arif Gosita, Masalah Perlindungan Anak, Akademika Pressindo, Jakarta, 1985, hlm. 18. 
memberikan sebuah ancaman yang nyata dan potensial bagi keberlangsungan hidup dan tumbuh kembang anak-anak, karena yang menjadi sesuatu tersebut tidak normal adalah kelainan perkembangan psikoseksual berupa individu memiliki dorongan seksual yang tidak normal terhadap anak-anak. ${ }^{15}$ Anak-anak dirayu dengan halus atau bahkan dipaksa dengan berbagai ancaman oleh orang dewasa yang memiliki kelainan seksual tersebut. Jadi dapat dipahami bahwa dari sisi perilaku maupun aktivitas seksual, pedofilia merupakan kejahatan yang hanya menyasar anak-anak sebagai korban. ${ }^{16}$

Dalam konteks Negara Kesatuan Republik Indonesia, konstitusi telah membuat peraturan secara tegas mengenai perlindungan anak. Undang-Undang Dasar 1945 Pasal 28B ayat (2) menyebutkan bahwa "Setiap anak berhak atas kelangsungan hidup, tumbuh dan berkembang serta berhak atas perlindungan dari kekerasan dan diskriminasi". Negara Indonesia dalam perkembangannya juga membuat peraturan yang lebih khusus mengenai perlindungan anak dengan mengeluarkan Undang-Undang Nomor 4 Tahun 1979 tentang Kesejahteraan Anak. Upaya untuk menangani perlindungan anak semakin terlihat setelah di 1990, pemerintah Indonesia secara resmi melalui Keppres No. 36/1990 meratifikasi konvensi tentang hak-hak anak yang menyampaikan amanat bahwa setiap anak berhak hidup sejahtera, perlindungan hukum untuk mencapai kesejahteraan anak wajib dijamin oleh negara.

Peraturan mengenai perlindungan anak di Indonesia yang lebih lengkap pada saat ini secara umum mengacu pada Undang-Undang Nomor 35 Tahun 2014 yang merupakan penyempurnaan atas Undang-Undang Nomor 23 Tahun 2002 tentang Perlindungan Anak. Selanjutnya disempurnakan lagi dengan Undang-Undang No. 17 Tahun 2016 tentang Penetapan Peraturan Pemerintah Pengganti Undang-Undang No. 1 Tahun 2016 tentang Perubahan Kedua Atas Undang-Undang No. 23 Tahun 2002 tentang Perlindungan Anak. Dalam undangundang tersebut pada ketentuan Pasal 1 angka 2 dijelaskan bahwa perlindungan anak adalah segala kegiatan untuk menjamin dan melindungi anak dan hakhaknya agar dapat hidup, tumbuh, berkembang, dan berpartisipasi secara optimal sesuai dengan harkat dan martabat kemanusiaan, serta mendapat perlindungan dari kekerasan dan diskriminasi. Anak dalam undang-undang tersebut yaitu seseorang yang belum berumur 18 tahun, termasuk anak yang masih dalam kandungan.

Menurut data dari Deputi Bidang Perlindungan Anak Kementerian Pemberdayaan Perempuan dan Perlindungan Anak sejak Januari hingga 31 Juli

15 Sawatri Supardi, Bunga Rampai Kasus Gangguan Psikoseksual, Refika Aditama, Bandung, 2005, hlm. 71.

16 Tini Rusmini Gorda, Hukum Perlindungan Anak Korban Pedofilia, Setara Press, Malang, 2017, hlm. 91. 
2020 sudah ada 4.116 kasus kekerasan pada anak di Indonesia yang sudah tercatat. Dari banyaknya kasus kekerasan pada anak tersebut, kasus paling banyak adalah kasus kekerasan seksual pada anak dengan rincian angka 2.556 korban kekerasan seksual. ${ }^{17}$

Data dari Kementerian Pemberdayaan Perempuan dan Perlindungan Anak pada 2021 telah tercatat sejak 1 Januari 2021 hingga 16 Maret 2021, terdapat 426 kasus kekerasan seksual dari total 1.008 kasus kekerasan terhadap perempuan dan anak. Kasus kekerasan pada perempuan dan anak merupakan fenomena gunung es, masih banyak kasus yang tidak terungkap dan dilaporkan. ${ }^{18}$

P. Cormil dalam penelitiannya pada 1959 menjelaskan bahwa korban patut mendapatkan perhatian dan bantuan yang lebih besar dan dilihat dari kriminologi maupun viktimologi harus diperhatikan dalam menyusun kebijakan kriminal dan juga dalam pembinaan para pelaku kejahatan. ${ }^{19}$

Dalam KUHP aturan mengenai perbuatan cabul ada pada Pasal 287, Pasal 290, Pasal 291, Pasal 292, Pasal 293, Pasal 294, dan Pasal 296 KUHP. Peraturan mengenai perbuatan cabul tersebut yang menempatkan anak-anak sebagai korbannya yang dilakukan oleh orang dewasa yang mengidap kelainan psikoseksual untuk melakukan kegiatan seksualnya dengan anak-anak, sehingga merupakan kebijakan formulatif terhadap pedofilia tertuang dalam Pasal 287, Pasal 290, Pasal 292, Pasal 293, dan Pasal 294 KUHP.

Peraturan yang ada dalam KUHP belum spesifik mengatur mengenai kejahatan pedofilia namun dapat diaplikasikan pada penjatuhan hukuman pada pelaku pedofilia. Namun dalam ketentuan pasal KUHP belum tercantum adanya upaya pecegahan yang dapat dilakukan. Selain KUHP di Indonesia juga menggunakan peraturan yang khusus mengenai perlindungan anak yaitu pada Undang-Undang Nomor 35 Tahun 2014 yang merupakan penyempurnaan atas Undang-Undang Nomor 23 Tahun 2002 tentang Perlindungan Anak.

Pasal 76D Undang-Undang Nomor 35 Tahun 2014 menjelaskan mengenai:

"Setiap orang dilarang melakukan kekerasan atau ancaman kekerasan memaksa anak melakukan persetubuhan dengannya atau dengan orang lain."

17 Sania Mashabi, Kementerian PPPA: Sejak Januari bingga Juli 2020 Ada 2.556 Anak Korban Kekerasan Seksual, diakses dari Kementerian PPPA: Sejak Januari hingga Juli 2020 Ada 2.556 Anak Korban Kekerasan Seksual (kompas.com), pada 19 Agustus 2021, pukul 14:51.

18 Sania Mashabi, Sejak Awal Januari, Kementerian PPPA Catat 426 Kasus Kekerasan Seksual, diakses dari Sejak Awal Januari, Kementerian PPPA Catat 426 Kasus Kekerasan Seksual (kompas.com), pada 19 Agustus 2021, pukul 15:02.

19 Dikdik M. Arief Mansur \& Elisatris Gultom, Urgensi Perlindungan korban Kejahatan antara Norma dan Realita, RajaGrafindo Persada, Jakarta, 2007, hlm. 41. 
Pasal 66 Undang-Undang Nomor 35 Tahun 2014 tentang Perlindungan Anak mengubah ketentuan Pasal 81 Undang-Undang Nomor 23 Tahun 2002 dengan menyatakan:

(1) Setiap orang yang melangggar ketentuan sebagaimana dimaksud dalam Pasal 76D dipidana dengan pidana penjara paling singkat 5 (lima) tahun dan paling lama 15 (lima belas) tahun dan denda paling banyak Rp. 5.000.000.000,00 (lima miliar rupiah).

(2) Ketentuan pidana sebagaimana dimaksud pada ayat (1) berlaku pula bagi setiap orang yang dengan sengaja melakukan tipu muslihat, serangkaian kebohongan, atau membujuk anak melakukan persetubuhan dengannya atau dengan orang lain.

(3) Dalam hal tindak pidana sebagaimana dimaksud pada ayat (1) dilakukan oleh orang tua, wali, pengasuh anak, pendidik, atau tenaga kependidikan, maka pidananya ditambah $1 / 3$ (sepertiga) dari ancaman pidana sebagaimana dimaksud pada ayat (1).

Pasal 76E Undang-Undang Nomor 35 Tahun 2014 menjelaskan mengenai:

"Setiap orang dilarang melakukan kekerasan atau ancaman kekerasan, memaksa, melakukan tipu muslihat, melakukan serangkaian kebohongan, atau membujuk anak untuk melakukan atau membiarkan dilakukan perbuatan cabul."

Perumusan Pasal 67 Undang-undang Nomor 35 Tahun 2014 tentang Perlindungan Anak mengubah ketentuan Pasal 82 Undang-Undang Nomor 23 Tahun 2002 tentang Perlindungan Anak, yang berbunyi:

(1) Setiap orang yang melanggar ketentuan sebagaimana dimaksud dalam Pasal 76E dipidana dengan pidana penjara paling singkat 5 (lima) tahun dan paling lama 15 (lima belas) tahun dan denda paling banyak Rp. 5.000.000.000,00 (lima miliar rupiah).

(2) Dalam hal tindak pidana sebagaimana dimaksud pada ayat (1) dilakukan oleh orang tua, wali, pengasuh anak, pendidik, atau tenaga kependidikan, maka pidananya ditambah $1 / 3$ (sepertiga) dari ancaman pidana sebagaimana dimaksud pada ayat (1).

Dilihat dari perumusan Pasal 82 ini dapat kita pahami bahwa pasal ini tidak khusus untuk menyelesaikan kasus pedofilia. Pasal ini dapat diberlakukan pada semua bentuk kekerasan dan kejahatan seksual yang korbannya adalah anak di bawah umur. Menjadi lebih khusus dalam rumusan pasal ini ialah ancaman pidananya. ${ }^{20}$

20 Tini Rusmini Gorda, Hukum Perlindungan Anak Korban Pedofilia, Setara Press, Malang, 2017, hlm 113114. 
Dalam Undang-Undang Perlindungan Anak belum memberikan gambaran tentang bagaimana pencegahan kejahatan seksual pada anak yang efektif. Padahal pencegahan kejahatan seksual pada anak atau pedofilia seharusnya mendapatkan perhatian lebih besar daripada tindakan represif atau penindakan kejahatan. Langkah pencegahan adalah lebih baik daripada tindakan represif dan koreksi. Usaha pencegahan tidak harus memerlukan suatu organisasi yang rumit dan birokrasi yang dapat menjurus ke arah birokratisme yang merugikan dan penyalahgunaan kekuasaan/wewenang. Upaya pencegahan adalah lebih mudah jika dibandingkan dengan usaha represif dan rehabilitasi. Untuk membantu dalam jumlah yang lebih besar, tidak pula diperlukan banyak dana dan tenaga seperti pada usaha represif dan rehabilitasi. Dalam upaya pencegahan tersebut juga tidak sendiri menimbulkan kejahatan.

a) Upaya pencegahan tidak perlu menimbulkan akibat yang negatif seperti antara lain: stigmatisasi (pemberian label pada yang dihukum, dibina, atau pada korban), pengasingan, berbagai penderitaan dalam banyak bentuk, pelanggaran hak asasi, permusuhan/kebencian terhadap satu sama yang lain yang dapat menjurus ke arah residivisme. Viktimisasi struktural (penimbulan korban oleh suatu sistem struktur) tertentu dapat diminimalisir dengan adanya usaha pencegahan tersebut, misalnya, korban suatu sistem penghukuman, peraturan tertentu, sehingga dapat mengalami penderitaan mental, fisik dan sosial.

b) Upaya pencegahan dapat pula mempererat persatuan, kerukunan dan meningkatkan rasa tanggung jawab terhadap sesama anggota masyarakat. Dengan demikian, upaya pencegahan dapat membantu orang mengembangkan manusia bernegara dan bermasyarakat yang lebih baik lagi. Oleh karena mengamankan dan mengusahakan keseimbangan dalam masyarakat yang diperlukan demi pelaksanaan pembangunan nasional untuk mencapai masyarakat yang adil dan makmur. Upaya pencegahan kejahatan dan penyimpangan lain dapat menjadi suatu usaha menciptakan kesejahteraan mental, fisik dan sosial masyarakat.

Mencegah orang berbuat tidak baik adalah sebuah kewajiban bersama terhadap sesama kita. Masyarakat wajib saling menjaga jangan sampai ada orang lain terjerumus, sesat dengan membiarkan orang lain merugikan orang hanya untuk kepentingan diri sendiri atau suatu golongan. ${ }^{21}$

Kendala yang nyata dihadapi para korban selain penderitaan fisik juga penderitaan psikis. Anak-anak korban kekerasan seksual mengalami trauma yang berat. Dalam beberapa kasus rehabilitasi traumatik tersebut membutuhkan waktu

${ }^{21}$ Arif Gosita, Masalah Perlindungan Anak, Akademika Pressindo, Jakarta, 1985, hlm. 110-111. 
1 sampai 3 tahun untuk penyembuhan. Akan tetapi untuk kembali pulih 100\% seperti semula tidak bisa karena jika ada pemicu yang mengingatkan korban maka luka batin tersebut tetap tidak bisa disembuhkan total. Kasus pedofilia memang seharusnya diselesaikan secara tuntas, tidak hanya didampingi untuk konseling namun harus dilakukan terapi yang panjang demi kesembuhan korban.

Selain terapi yang dilakukan kepada korban, perlu juga diadakan terapi pada keluarga. Keluarga yang menjadi pendukung utama kesembuhan korban perlu disiapkan untuk menangani permasalahan ini. Keluarga harus memahami apa yang terjadi dan apa yang harus dilakukan untuk mendukung kesembuhan anak karena tak jarang keluarga juga tidak paham dan tidak tahu apa yang harus dilakukan. Lingkungan masyarakat juga seharusnya memberikan dukungan yang positif dan tidak memberikan stigma buruk bagi korban karena dalam hal ini korban juga tidak menginginkan hal buruk itu terjadi.

Permasalahannya adalah rehabilitasi untuk menyembuhkan kerusakan psikis para korban memakan biaya yang sangat banyak. Anak membutuhkan kira-kira 40 kali konseling dan terapi penyembuhan psikis. Belum ada dana dari pemerintah atau BPJS untuk menanggung biaya rehabilitasi sebanyak itu. Dana yang dapat digunakan adalah bantuan dari LPSK untuk melakukan visum untuk mencari bukti.

Korban para pelaku pedofilia ini jika tidak direhabilitasi dikhawatirkan akan muncul dua kemungkinan. Pertama adalah anak korban pedofil tersebut mengalami ketakutan, trauma, depresi dan lain-lain. Di satu sisi korban pedofilia tersebut dikhawatirkan akan ketagihan, menikmati, ingin mengulangi dan lebih parah akan mencari korban lain untuk dijadikan pelampiasan. Hal tersebut yang menjadikan permasalahan ini menjadi sangat kompleks dan sulit untuk memutus rantai penyebaran kejahatan pedofilia. ${ }^{22}$

Sebenarnya pemerintah dalam hal menanggulangi permasalahan perlindungan anak tidak hanya bergantung pada KPAI, pemerintah juga membuat beberapa program seperti Bina Keluarga Balita, Bina Keluarga Remaja untuk menunjang berbagai usaha perlindungan anak. BKKBN juga membuat sebuah program PIK-R yaitu Pusat Informasi Kesehatan Reproduksi Remaja. Ada konseling yang disediakan untuk remaja yang membahas seksualitas dan lainlain.

Di Yogyakarta ada program Kampung Ramah Anak, dalam program tersebut merupakan bagaimana suatu desa/kampung secara tersistem dapat memenuhi pemenuhan dan perlindungan hak anak salah satunya pada kekerasan

${ }^{22}$ Hasil wawancara penelitian dengan Ifa Aryani, Selaku Staff Bidang Sosialisasi dan Advokasi KPAID Yogyakarta, pada 9 April 2021. 
pada anak. Selain itu ada program forum anak. Forum anak tersebut dibagi menjadi dua yaitu pelopor dan pelapor. Jadi, jika ada kejadian yang berkaitan dengan anak-anak maka segera dilakukan pelaporan ke instansi terkait. Program forum anak tersebut ada dibawah Badan Pemberdayaan Perempuan, Perlindungan Anak, Pengendalian Penduduk dan Keluarga Berencana atau BP3AP2KB.

Ada banyak progam-program pemerintah yang telah dilakukan seperti SIGRAK (Siap Gerak Atasi Kejahatan Terhadap Anak), PUSPAGA Pusat Pembelajaran Keluarga, Mitra Keluarga, Satgas Perlindungan Perempuan dan Anak, PATBM atau Pusat Perlindungan Anak Terpadu Berbasis Masyarakat. Program-program tersebut ada yang diselenggarakan oleh pemerintah pusat, Kabupaten Kota Layak Anak, dan UPT PPA atau Unit Perlindungan Terpadu Perempuan dan Anak. ${ }^{23}$

Sangat jelas di sini bahwa masyarakat perlu ikut dalam melaksanakan dan menjalankan perlindungan anak bersama pemerintah karena permasalahan kekerasan seksual pada anak atau pedofilia merupakan permasalahan yang kompleks. Hal tersebut juga ada dalam ketentuan Pasal 72 Undang-Undang Nomor 35 Tahun 2014 tentang Perlindungan Anak. Usaha pemerintah dalam membuat berbagai program tersebut harus benar-benar didukung oleh masyarakat agar terciptanya perlindungan hukum bagi anak-anak.

\section{Cara Melindungi dan Mencegah Anak dari Tindak Pidana Pedofilia}

Tindakan nyata demi melindungi anak-anak harus selalu dilakukan dan dikampanyekan kepada seluruh lapisan baik masyarakat, organisasi masyarakat, pemerintah dan negara. Tidak cukup hanya dengan melakukan pembuatan undang-undang dan ketentuan lainya. Beberapa upaya pencegahan yang dapat dilakukan untuk mencegah terjadinya kejahatan kekerasan seksual pedofilia adalah sebagai berikut:

a) Keluarga menjadi upaya pencegahan pertama bagi keselamatan anak-anak. Keluarga harus memberikan edukasi kepada anak mengenai pendidikan, kesehatan reproduktif dan seksualitas, serta mengenali bagian-bagian sensitif tubuh.

b) Mencegah kematangan seksual lebih dini. Masa kini anak mengalami kematangan seksual lebih cepat, hal tersebut dipengaruhi oleh lingkungan, makanan dan teknologi.

c) Melangsungkan komunikasi yang terbuka dalam keluarga agar anak menceritakan apapun kepada orang tua dan tidak dipendam sendiri.

${ }^{23}$ Hasil wawancara penelitian dengan Ifa Aryani, Selaku Staff Bidang Sosialisasi dan Advokasi KPAID Yogyakarta, pada 9 April 2021. 
d) Mewaspadai orang dewasa yang sering dikerubungi oleh banyak anakanak.

e) Memberikan fasilitas publik yang berdampak positif kepada anak seperti ruang terbuka hijau atau taman kota yang mudah dipantau. ${ }^{24}$

f) Pelaksanaan penyuluhan atau himbauan kepada masyarakat untuk saling menghargai, melindungi hak dan harga diri anak-anak di lingkungan masyarakat.

g) Meningkatkan kewaspadaan masyarakat untuk menghindari terjadinya tindak pidana kesusilaan dan kekerasan seksual anak atau pedofilia yang dapat dimulai dari keluarga untuk lebih memperhatikan setiap anggota keluarganya masing-masing khususnya anggota keluarga yang dewasa kepada anak-anak.

h) Meningkatkan kesadaran masyarakat mengenai langkah-langkah praktis dalam penanganan diri di setiap pergaulan di lingkungan masyarakat untuk mengantisipasi terjadinya tindak pidana.

i) Memberikan himbauan kepada masyarakat untuk segera melapor ke pihak yang berwajib apabila terjadi suatu tindak pidana baik yang menimpa dirinya maupun orang lain. ${ }^{25}$

Dalam usaha memberikan perlindungan hukum terhadap korban kekerasan seksual tentunya akan ada banyak kendala yang dihadapi. Beberapa kendala atau halangan yang sering terjadi adalah:

1) Korban memutuskan untuk tidak melaporkan kejadian yang dialaminya karena ia merasa malu dengan kejadian tersebut yang ia pikir merupakan sebuah aib bagi dirinya dan keluarganya. Selain itu seringkali ada ancaman yang dilakukan oleh pelaku sehingga korban menjadi tertekan dan takut untuk memberitahu kejadian yang dialaminya kepada orang lain dan takut melapor kepada pihak yang berwajib;

2) Pihak keluarga dan lingkungan masyarakat yang belum mengerti sepenuhnya mengenai tindak pidana kekerasan seksual yang terjadi dan sering menyalahkan korban atas kejahatan yang dialaminya;

3) Dilakukannya pencabutan laporan dari pihak korban, karena adanya permintaan dari pelaku untuk menyelesaikan kasus tersebut secara kekeluargaan (pencabutan laporan) yang mengakibatkan kasus tersebut tidak dapat diselesaikan dengan proses hukum yang berlaku sehingga pengungkapan kasus tersebut berhenti;

4) Tersangka sering melarikan diri dan kondisi tersebut menyulitkan pihak kepolisian karena tidak adanya tersangka maka kasus tidak dapat diproses secara hukum;

${ }^{24}$ Hasil wawancara penelitian dengan Ifa Aryani, Selaku Staff Bidang Sosialisasi dan Advokasi KPAID Yogyakarta, pada 9 April 2021.

25 Ario Ponco Wiguno, “Kajian Viktimologi Terhadap Anak Sebagai Korban Tindak Pidana Kesusilaan”, Jurnal Ilmu Hukum Legal Opinion, Edisi I, Vol 1, 2013, hlm. 6-7. 
5) Perkosaan dan kekerasan seksual yang terjadi sering dilakukan pada malam hari dan hal ini menyebabkan kurangnya bahkan tidak adanya saksi yang melihat;

6) Sarana dan prasarana pendanaan merupakan hal yang penting namun belum cukup memadai, dimana dengan pendanaan yang cukup dimungkinkan akan mempermudah dan memperlancar proses hukum;26 dan

7) Kurangnya bukti yang diperoleh dalam suatu kasus, bila korban tidak mengalami trauma dengan Visum et Psikiatrikum maka sulit untuk membuktikan adanya kekerasan seksual. ${ }^{27}$

\section{Penutup}

Berdasarkan dari uraian di atas, maka penelitian ini menyimpulkan: pertama, pemerintah dengan berbagai upaya melalui program edukasi dan sosialisasi kepada masyarakat mengenai permasalahan anak tersebut masih beberapa kali mendapati laporan tentang adanya kasus dan korban. Pembaharuan hukum yang sudah diperbarui hingga dua kali yaitu UndangUndang Nomor 35 Tahun 2014 yang merupakan penyempurnaan atas UndangUndang Nomor 23 Tahun 2002 tentang Perlindungan Anak selanjutnya disempurnakan lagi dengan Undang-Undang No. 17 Tahun 2016 tentang Penetapan Peraturan Pemerintah Pengganti Undang-Undang No. 1 Tahun 2016 tentang Perubahan Kedua Atas Undang-Undang No. 23 Tahun 2002 tentang Perlindungan Anak dengan ditambahkannya pemberatan hukuman dan hukuman tambahan sepertinya masih belum efektif menanggulangi permasalahan pedofilia. Perlindungan hukum dan pencegahan secara tidak langsung kepada anak seperti pembuatan undang-undang dan pemberatan hukuman hanya ditujukan kepada orang dewasa yang bahkan orang dewasa tidak semuanya memahami adanya hukum tersebut.

Kedua, dibutuhkan perlindungan hukum dan pencegahan secara langsung seperti pemberian materi edukasi pada anak, pengawasan pada lingkungan anakanak, dan pendataan secara berkala akan tumbuh kembang anak agar anak merasa aman dan terlindungi. Pemutusan rantai pedofilia juga harus menjadi fokus pemerintah dan masyarakat agar tindak pidana pedofilia tidak terulang kembali. Pemerintah harus benar-benar menuntaskan permasalah yang ada pada para pelaku dan korban. Pelaku harus diawasi jangan sampai terulang melakukan tindakannya kembali. Sedangkan untuk para korban harus selalu didampingi dan

\footnotetext{
${ }^{26}$ Ibid., hlm 6.

${ }^{27}$ Hasil wawancara penelitian dengan Ifa Aryani, Selaku Staff Bidang Sosialisasi dan Advokasi KPAID Yogyakarta, pada 9 April 2021.
} 
dilakukan rehabilitasi dan terapi agar kesehatan fisik dan psikis korban kembali utuh seperti semula dengan tujuan para korban tidak menjadi seorang pelaku pedofilia di kemudian hari.

\section{Daftar Pustaka}

\section{Buku}

Arief Mansur, Dikdik M. \& Gultom, Elisatris, Urgensi Perlindungan korban Kejahatan antara Norma dan Realita, RajaGrafindo Persada, Jakarta, 2007.

Dellyana, Shanty, Wanita dan Anak di Mata Hukum, Liberty, Yogyakarta, 2004.

Gorda, Tini Rusmini, Hukum Perlindungan Anak Korban Pedofilia, Setara Press, Malang, 2017.

Gosita, Arif, Masalah Perlindungan Anak, Akademika Pressindo, Jakarta, 1985.Gultom, Maidin, Perlindungan Hukum Terhadap Anak dan Perempuan, Refika Aditama, Bandung, 2018.

Huraerah, Abu, Kekerasan Terhadap Anak, Nusantara, Bandung, 2006.

Mertokusumo, Sudikno, Mengenal Hukum (Suatu Pengantar), Liberty, Yogyakarta, 1999.

Supeno, Hadi, Kriminalisasi Anak, Gramedia Pustaka Utama, Jakarta, 2010.

Supardi, Sawatri, Bunga Rampai Kasus Gangguan Psikoseksual, Refika Aditama, Bandung, 2005.

Suparti Sadarjoen, Sawitri, Bunga Rampai Kasus Gangguan Psikoseksual, Refika Aditama, Bandung, 2005.

\section{Jurnal}

Ario Ponco Wiguno, "Kajian Viktimologi Terhadap Anak Sebagai Korban Tindak Pidana Kesusilaan", Jurnal Ilmu Hukum Legal Opinion, Edisi I, Vol 1, 2013.

Muhammad Zubedy Koteng, "Upaya Pencegahan Dan Penangnan Kejahatan Seksual Terahadap Anak", Warta Hukum dan HAM, Humanis Volume 1 XII Juli 2016.

Ratna Sari, et.al., "Pelecehan Seksual Terhadap Anak", Riset E PKM, edisi No. 1 Vol. 2, 2015.

\section{Internet}

"WNA Pedofil Kerap Pukuli Korbannya", https://republika.co.id/berita/ qd8j0u330/wna-pedofil-kerap-pukuli-korbannya, diakses pada 22 Juli 2020.

"KPAI: Kekerasan Anak Laki-Laki Meningkat", https://www.kpai.go.id/ berita/kpai-kekerasan-seksual-anak-laki-laki-meningkat, diakses pada 6 April 2020

"Pelaku Pedofil di Sukabumi Cabuli 30 Anak Laki-laki, Tulis Nama Korban di Tembok Kamar", https://www.tribunnews.com/regional/2020/07/06/ pelaku-pedofil-di-sukabumi-cabuli-30-anak-laki-laki-tulis-nama-korbandi-tembok-kamar?page=all, diakses pada 7 Juli 2020. 
"Kementerian PPPA: Sejak Januari hingga Juli 2020 Ada 2.556 Anak Korban Kekerasan Seksual", diakses dari Kementerian PPPA: Sejak Januari hingga Juli 2020 Ada 2.556 Anak Korban Kekerasan Seksual (kompas.com)), pada 19 Agustus 2021.

"Sejak Awal Januari, Kementerian PPPA Catat 426 Kasus Kekerasan Seksual", diakses dari Sejak Awal Januari, Kementerian PPPA Catat 426 Kasus Kekerasan Seksual (kompas.com), pada 19 Agustus 2021.

"Ngakunya Perlindungan Anak Ternyata Biadab", https: / / regional.kompas.com/read/2020/07/05/16000071/-ngakunyaperlindungan-anak-ternyata-biadab-?page=all\# page2 diakses pada $22 \mathrm{Juli}$ 2020.

\section{Hasil Wawancara}

Hasil wawancara penelitian dengan Ifa Aryani, Selaku Staff Bidang Sosialisasi dan Advokasi KPAID Yogyakarta, pada 9 April 2021.

\section{Peraturan Perundang-Undangan}

Undang-Undang Nomor 23 Tahun 2002 tentang Perlindungan Anak. 